\title{
An Evaluation of Holsti's Concept of Foreign Policy Restructuring: Has FPR Been Sufficiently Covered in the Arab World?
}

\author{
Hoda Fadel Shaltout ${ }^{1}$ \\ ${ }^{1}$ Political Sciences Faculty, Cairo University, Egypt \\ Correspondence: Hoda Fadel Shaltout. E-mail: hodashaltout@yahoo.com
}

$\begin{array}{lrr}\text { Received: May 5, } 2018 & \text { Accepted: May 11, } 2018 & \text { Online Published: July 27, } 2018 \\ \text { doi:10.5539/ass.v14n8p44 } & \text { URL: https://doi.org/10.5539/ass.v14n8p44 }\end{array}$

\begin{abstract}
Using Holsti's pioneer work on the concept of foreign policy restructuring (FPR) as the yardstick theoretical framework, the article critically assesses its impact on the literature with particular emphasis on the Arab World. The article's aim is to solve the puzzle involving the diffident reference to Hoslti's work, the extent to which FPR has been covered in the Arab World and, in case of a modest contribution, the factors causing such lack of attention to that particular field of study in the region. It specifically questions the existence of an explicit substantive and geographical literature gap, notwithstanding the efforts of successive scholars, the centrality of the Arab region, and the tremendous changes that hit a number of countries within it since the end of 2010 and on. Such state of affairs, not only amplifies the heavy cost of the current gap but also loudly echoes urgent calls to address it. The hypothesis is that such situation is inherently due to structural limitations within Holsti's work and the scarcity of subsequent efforts to develop the concept further as well as, as far as the Arab World is concerned, regional inherent methodological factors. The author will follow an analytical and descriptive approach to trace the available literature with emphasis on Holsti's work and key subsequent efforts. The article concludes by underlining the urgent need for a fresh and continuous work on studying FPR in the Arab World considering the critical role that part occupies in global politics.
\end{abstract}

Keywords: Bahgat Korany \& Ali E. Hillal Dessouki, Charles Hermann, Foreign policy restructuring, Foreign policy restructuring in the Arab World, Jerel Rosati, Kalevi Holsti

\section{Introduction}

The gigantic political, social, and security earthquakes that a number of countries in the Arab World have experienced, since the end of 2010 and on, compels extreme attention across, inter alia, academic and scholarly disciplines. The impact was not limited domestically but was far beyond expectations on a plethora of levels. Not only has it touched various personal aspects of people's lives at the respective countries' national level, either by igniting civil wars, forcing internal or across the border displacements, altering social fabric, and imposing harsh economic cost and a human one in some cases, but over and above it has disproportionally expanded its reach to involve proxy wars that has implicated global powers, as well as regional ones, in fierce struggle for taking advantage of the dynamically fluid balance of power with its associated opportunities as well as inevitable risks. Though the situation in some countries has boiled down to a relative degree of stability, including in Tunisia and Egypt, the context is far more complicated in other countries including Libya, Yemen, and Syria where the last two are clearly demonstrating the regional strive for hegemony specifically the latter which goes beyond that to global realms of struggle. In the midst of such unequivocal waves of radical change induced by multi-faceted and intertwined factors and involving complex and diverse dimensions, there seems to have been an unbalanced interest and scholarly temptation in emphasizing the regional political dynamics, not to mention the global ones, at the expense of the deep analysis of factors and reasons behind FPR within those specific countries or others which were directly or indirectly affected by such radical changes. Without a thorough analysis of such changes and the rationale behind them, it will be difficult or even impossible to comprehend or anticipate the actions of states in general, and Arab ones in particular, when it comes to the conduct of their foreign policies and hence their pursuit of their national interest. Though Holsti has coined the term of FPR in the early 1980s to denote behavior where governments seek to change, usually simultaneously, the total pattern of their external relations (Holsti, 1982), the article will demonstrate that no in-depth studies have covered the current state of FPR affairs in the Arab World compared to, for instance, the ones that analyzed Nasser's or Sadat's own FPR (Dessouki, 
2008; Karawan, 2006). This obvious gap in the literature dictates a closer analysis to highlight the rise of the original concept and the efforts of following scholars to identify the contributing factors to such modest or even non-existent attention towards the study of FPR in the Arab World.

\section{Methodology}

\subsection{The Problem}

Despite of the then thrust that accompanied the rise of foreign policy change and the coining of the FPR concept in particular, the utilization of Holsti and subsequent developments of the concept were disproportionate particularly with regard to the Arab World, a highly problematic fact considering the fundamental changes that are taking place within the region underlining an urgent need to tackle the gap.

\subsection{Research Questions}

- How has foreign policy change paved the way for FPR?

- What was the role of Holsti and what was his impact on the literature?

- What were the subsequent efforts to advance Holsti's idea?

- What efforts has so far been directed towards FPR in the Arab World and what was its added value if any?

- Why the interest in the Arab World in the first place and why the attention now should be more than ever?

\subsection{Hypothesis}

The underdeveloped status of the FPR relates to structural limitations of Holsti's concept as well inherent methodological flaws and negligence to the foreign analysis discipline in the Arab World.

\subsection{Research method}

The author uses a deductive approach building up on a thorough analysis of available resources on the evolution of FPR with the provision of real case studies when available and relevant.

\subsection{Results}

- Holsti's concept has not been sufficiently inclusive nor up to date to cater for contemporary developments and accordingly has been modestly utilized

- Subsequent efforts to advance the concept were equally diffident, or not up to date, particularly with regard to linking it to practical developments occurring on ground in the Arab World.

\section{Literature Review}

\subsection{Contemporary Evolution of the Study of Foreign Policy}

Foreign policy is a very old discipline which encompasses a complex inter-state process of interaction. Though the term evolved in its most primitive forms with the rise of diplomacy more than 2000 years from Thucydides through Machiavelli to Grotius, it came into increasing use during the $18^{\text {th }}$ century and onwards, particularly with the enhanced sophistication of government bureaucratic structures and the creation of ministries of foreign affairs (Hill, 2003). The $19^{\text {th }}$ and $20^{\text {th }}$ centuries witnessed gigantic expansion in the utilization of the phrase in both theory and practice, particularly with the accelerated advance in communication and transportation means, taking the inter-states' relations into new horizons of interaction, with regard to frequency of contact on one hand, but also the expansion of its subjects (states, governmental and non-governmental international organization, individuals, MNCs ... etc.), and the increasing complexity and diversity of the subject-matters (Wallace, 1997).

Though the field of study received such a thrust, its dynamic aspects, continued to receive scarce attention as analysts were tempted to focus more on stability (Gustavsson, 1998). Robert Gilpin referred to a number of contributing factors, namely a need to apprehend statics before moving on to more convoluted dynamics, a pervasive disbelief in the possibility to make generalizations about change, and a normative prejudice in favor of permanency (Gilpin, 1981). In a similar vein, Holsti (1998) argued that change was overlooked for a protracted duration of time due to a strong obsession with the perceived constancy of the Cold War era, as well as an overly exaggerated conviction in the stabilizing effects of interdependence. A central assumption was that foreign policies tend to be rigid; once a particular policy was in place, presumably inherent institutional inertia and stakes have a stabilizing effect, making it highly resistant to alteration (Gustavsson, 1998). Hermann in turn contended that such neglect has been partially responsible for crippling the provision of more adequate and comprehensive explanations of foreign policy (Hermann, 1978). 


\subsection{The Rise of Foreign Policy Change as a Focus of Analysis}

That said, the initial contemporary interest in studying change as a field of international relations grew back in the 1970s and continued to evolve in the 1980s (Gustavsson, 1998). It then gained further momentum in the early 1990s inspired by the momentous events affiliated with the collapse of the Soviet Union stirring further attention to understanding the phenomenon of foreign policy change, its types, variables that influence such change, and, most importantly, the reasons that motivate such change (Gustavsson, 1998).

Rosenau was one of the first in the international relations' filed who defined foreign policy in terms of change (Holsti, 1998). Rosenau (1990) argued that foreign policy is fundamentally a mechanism for a nation to adapt to or deal with changes taking place in relevant arenas. He addressed most of the problems of change (Rosenau, 1990) - the critical importance of time perspectives, philosophies of history, the scope and levels of change (local, regional, and global) and the extent to which "turning points," "tectonic shifts", and other markers or metaphors of change, were the analyst's arbitrary designations (Holsti, 1998). Additionally, he insisted that the analyst or observer should establish specific benchmarks against which change was measured (Holsti, 1998).

The interest in the study of foreign policy change developed rapidly (Gustavsson, 1998) but there was more than just simple change in the theoretical air (Holsti, 1998; Rosati et al., 1994). The end of the Cold War stimulated a large industry of projections for the future. Most of these heralded significant changes in the texture, structures, and practices of international relations. Various authors (Goldgeier \& McFaul, 1992; Singer \& Wildavsky, 1993; Koslowski \& Kratochwil, 1994) saw the end of the Cold War as creating, at a minimum, a fundamental change in the way the superpowers related to each other and, at a maximum, a true transformation of the international system (Goldgeier \& McFaul, 1992; Singer \& Wildavsky, 1993; Koslowski \& Kratochwil, 1994). Others spoke of a novel era encompassing major transformations (Sakamoto, 1994), post-international politics (Rosenau, 1990) and "epochal transformation" (Rosenau, 1997), the changing of the very rules of the game of international relations (Kamo, 1994), and the change of system rather than a change within the system (Koslowski \& Kratochwil, 1994). Commenting on the exceptional distinction of that period, Hoffman argued:

"There are periods of history when profound change occur all of a sudden and the acceleration of events is such that much of what experts write is obsolete before it gets into print. We are now in one if these periods" (Hoffman, 1989).

In contrast to normal change, the experienced one was not only significant and entirely new, but it was also comprising the antithesis of something old. For Mueller and Fukuyama, peace replaced war (Mueller, 1989; Fukuyama, 1989). For Huntington, civilizational wars replaced inter-state wars (Huntington, 1993). For other scholars, the relative stability of the Cold War was substituted by the "coming chaos" of armed conflict in the Third World, and while whether such fluctuations were true transformations can be debated endlessly, all the authors took a joint position in their implied conception of change (Goldgeier \& McFaul, 1992; Singer \& Wildavsky, 1993; Kaplan, 1994). According to Holsti, "this is a discontinuous idea of change: new ones replace old forms, so the problem of transformation does not arise" (Holsti, 1998).

\subsection{Holsti and the Concept of Foreign Policy Restructuring}

In linkage to the profound foreign policy change, this article's theoretical framework focus is beyond the ordinary change of foreign policy, and mainly with the radical change that occurs when governments seek to alter, usually the aggregate pattern of partnerships or cooperation with other states. This is what Holsti termed Foreign Policy Restructuring, or otherwise referred to in this article as FPR.

In his book 'Why Nations Realign: Foreign Policy Restructuring in the Postwar World', Holsti and others analyzed the process of radical foreign policy change - how states restructure their foreign relations, and why they do so (Holsti, 1982). The book comprised a collection of essays which observed examples of FPR in the Third World and in small states, in addition to Canada and France. The initial chapter, written by Holsti, provided a theoretical framework for the description and explanation of FPR. In the subsequent eight case studies of states' foreign policy conduct over the period 1957-80, Holsti and others explored the sources of successful and abortive FPR. The case studies distinguished between sporadic or fragmentary foreign policy change and adaptation on one hand, and the fundamental reordering of foreign policy at the other end (Holsti, 1982).

Holsti defined FPR as a type of foreign policy behavior where governments seek to change, usually simultaneously, the total pattern of their external relations (Holsti, 1982). Compared to normal foreign policy change, which was incremental, slow, with little spillovers between geographic or functional sectors, and typified by low linkages between prospectors, FPR on the other hand stroke the roots of existing orientation; it 
was non-incremental, abrupt, expressed an intent for fundamental change, and usually involved the conscious linking of different sectors (Holsti, 1982).

Holsti stated that the FPR was often a response to a threat, but not always a military one. In the modern era, threats could be cultural, environmental, social, security-related, political, informational, economic, etc., a point equally echoed by Korany \& Dessouki where they have highlighted the impact of other factors, other than wars, in transforming the global system (Korany \& Dessouki, 2008). Diverse and multiple processes associated with growing interdependence usually drive the threats. Hence, FPR can result from military and strategic concerns, domestic and external conditions, such as economic vulnerability, social consequences of modernization, dependence, ideological disputes between factions, xenophobia, neo colonialism, nationalism, etc. (Holsti, 1982).

Holsti further explained the typology of FPR. He argued that types of reorientation and FPR can be distinguished on the basis of significant changes in the levels of external involvement, policies regarding types and sources of external penetration, directions or pattern of external involvement, as well as military or diplomatic commitment leading to one of the following potential outcomes: isolation, self-reliance, dependence or non-alignment/diversification (Holsti, 1982). These four types, coupled with the intent to restructure, form the basis for the dependent variables in the study. The independent variables included external military and non-military threats, internal economic conditions, domestic factors, as well as colonial experiences and attitudes toward foreigners embedded in the history and culture of a society. Perceptions held by policy makers, their personality characteristics and attitudes toward external actors, and the policy making process, represented the intervening variables (Holsti, 1982).

Rosenau's contribution was describing what he perceived as happening to nations when they make changes in foreign policy. Holsti's addition was that he began to theorize as to what is happening when nations adjust their foreign policy. He identified 13 types of FPR outcomes a nation state can make over time. The framework of his model focused on the roles of external factors, domestic factors, background historical and cultural factors, and factors within policymaking process itself (Holsti, 1982).

\subsection{Evaluating the Contribution of Holsti}

Generally speaking, Holsti's FPR work was surely a pioneer one. He was able to identify certain conditions that would predispose a state to restructure its foreign policy in response to threats. His study also provided an excellent opportunity to examine the factors that can prevent FPR at the state level. Before exploring the potential setbacks of his work, and to fairly and scientifically assess the impact of Holsti's FPR model on the relevant literature, a thorough screening proved enlightening.

In evaluating Holsti's contribution, it is evident that his ideas had a minor influence on the literature. For the following twenty years after the publication of his book, Holsti's model impact on the concept of FPR appeared insignificant. Though the concept became more frequently used to denote a particular foreign policy change, the amount of references to Holsti in articles and academic studies illustrated the aforementioned conclusion.

As a start, a thorough screening of major political science journals, namely World Politics, American Political Science Review, and the British Journal of Politics and International Relations, revealed that the mention of FPR in linkage to Holsti over the period of 1982-2000 was limited to two single times in 2009 and 2014 within the American Political Science Review respectively, and in both instances the mention offered a review of Holsti's 1982 edited book "Why Nations Realign: Foreign Policy Restructuring in the Postwar World".

A general search on the internet for both PHD and master theses, articles, and papers that referred to FPR disclosed a record of 17 times, namely nine theses and eight articles/research papers respectively. The lack of reference, mere or group reference, non-preferential references, or thorough reference, can be classified into four categories.

The first category was the ones which touched in a way or another on FPR but did not mention Holsti at all. Those encompassed an online 2014 paper by Igor Castellano da Silva titled "Foreign Policy in Southern Africa: Causes of Changes in the Pattern of Cooperation-Conflict (1975-2010)" which referred to FPR and cited Dessouki (2008), an online 2013 thesis by James Brodie LeBlue titled "Is Turkey's Foreign Policy Moving East?" which touched on FPR but referred to Muhittin (2002), an online 2013 article by Peter Rudloff titled "Offensive Realism, Defensive Realism, and the Role of Constraints" which touched, inter alia, on FPR while referring solely to Rosati and others (1994), an online 2010 paper by Fredrick Doeser titled "International Constraints, Domestic Politics and Foreign Policy Change in Small States: The Fall of the Danish "Footnote Policy" which did not mention Holsti, and an online 2006 paper by Segbers/Dyllick-Brenzinger/Hoffmann/Mauersberger titled 
"Global Politics: How to use and Apply Theories of International Relations" which solely referred to Rosati (1994).

The second category encompassed those sources which touched on Holsti but preferred to apply the model of others. Those comprised an online 2013 thesis by Luong Ngoc Thanh titled "Vietnam's Foreign Policy in the post-Cold War Era: Ideology and Reality" which referred to the models of Rosenau (1981), Holsti (1982), Goldmann (1988) but particularly focused on Hermann (1990), an online 2010 paper by Spyros Blavoukos \& Dimitris Bourantonis titled "Accounting for foreign policy change: the role of policy entrepreneurs" which mentioned Holsti once while referring to the past disinterest in foreign policy change before switching to Hermann (1990) to discuss the different levels of FPR, and an online 2009 thesis by Yasser Mohamed Elwy Mohamed Mahmoud titled "A Political Economy of Egyptian Foreign Policy: State, Ideology, and Modernization since 1970" which referred to Holsti's FPR and his usage of Egypt as an example in the introduction of his 1982 collections of essays but eventually referred to Rosati (1994), Rosati and others (1994), and Dessouki (1997) as the most recent contributors of collected essays on the subject.

The third category referred to Holsti either solely, but not deeply, or as one among other contributors to the field, including an online 2016-2017 thesis by Nils Knudsen Vardam titled "Continuity or change? U.S. foreign policy decision-making during the wars in Georgia and Ukraine", Swedish Defence University, where the author merely referred to Holsti when defining FPR, an online 2016 article by Maung Aung Myoe titled "Myanmar's Foreign Policy under the USDP Government: Continuities and Changes" which referred to Holsti's definition of FPR and types of change, an online 2014 thesis by Anuar Ayazbekov titled "Independent Kazakhstan and the 'Black Box' of Decision-Making: Understanding Kazakhstan's Foreign Policy in the Early Independence Period (1991-4)" which suggested in a footnote Holsti among others for a detailed discussion of FPR, an online 2013 article by Ítalo Beltrão Sposito titled "Foreign Policy Change in Brazil: Comparing Castelo Branco (1964-1967) and Fernando Collor (1990-1992)" which touched on FPR typologies, and accordingly referred to Holsti (1982), Hermann (1990), Rosati (1994), and Rosati and others (1994), an online 2012-2013 thesis by Saad Al-Habida titled "the Iranian Nuclear Program and its Impact on the direction of the Kuwaiti Foreign Policy" where the author referred to Holsti arguments in relation to the author's theoretical framework, an online 2012 thesis by Mina Ishak Tanyous titled "Democratic Transformation and Change in the Foreign Policy: A Study of North Korea's Policy towards South Korea", an online 2012 thesis by Arthur Minsat titled "Making EU Foreign Policy towards a 'Pariah' State: Consensus on Sanctions in EU Foreign Policy towards Myanmar' which suggested in a footnote Holsti among others for detailed discussion of FPR, an online 2012 thesis by Davut Han Aslan titled 'Turkey's Foreign Policy of the Justice and Development Party Governments (2002-2011)" which referred to Holsti's model particularly in relation to the role of domestic politics and the role of the leader, an online 2009 research paper by Spyros Blavoukos and Dimitris Bourantonis titled "Identifying Parameters of Foreign Policy Change: A synthetic Approach" where the authors referred to Holsti (1982 \& 1995) but emphasized Hermann, C. (1990), Hermann, M. (2001), Hermann, M. and others (2001), and Rosati and others (1994), an online 2008 research paper by Vinsensio Dugis titled "Explaining Foreign Policy Change" which referred to Holsti (1982 \& 1983) but also to Rosenau (1972, 1974, \& 1976) and Hermann (1990), an online 2006 article by Thomas Niklasson titled "Regime Stability and Foreign Policy Change: Interaction between Domestic and Foreign Policy in Hungary 1956-1994" where the author discussed change and referred to Holsti (1982), Hermann (1990) and Rosati and others (1994) and others, an online 1989 research article by Joe D. Hagan titled "Domestic Political Regime Changes and Foreign Policy Restructuring in Western Europe: A conceptual Framework and Initial Empirical Analysis" where the author referred to Holsti (1982) but primarily to Hermann, M. (1980 \& 1982) and Hermann, M. \& Hermann, C. and others (1982 \& 1987), and an online undated paper by Bear F. Braumoeller titled "The Myth of American Isolationism" which briefly referred to Holsti (1982) and Rosati and others (1994) when discussing FPR. Other works that merely mentioned Holsti as one among other contributors in the FPR field included the 2015 and 1998 ones of Nourhan El-Sheikh titled "Theory of International relations" and Mohamed El-Sayed Selim titled "Analysis of Foreign Policy".

The fourth and last category, used Hoslti's entire model as the backbone for the theoretical framework and that involved one online 1993 master thesis by Lizhu Zhang on "comparative study of Chinese foreign policy restructuring", University of Windsor, where the author completely relied on Holsti's concept of FPR as a theoretical framework for the study. The author dedicated the entire first chapter, over some 20 pages, for what he called the 'Holsti model and its applicability'.

In the same vein, reviews saw that Holsti's theoretical framework would have benefited from a discussion of the probability that each of the orientations might be transformed to each of the others, and what type of variables might be expected to play a role in proceeding such a transformation. Another possible setback was his inability 
to explain why two states in the same situation and under same threats would not follow the same path of change. Last but not least, the examples used in his 1982 book were highly influenced by the then prevailing international set-up influenced by Cold War era and its unique dynamics and which was primarily used as the book's yardstick for analysis. This is unfortunate, since more explicit and up to date references, in a vigorously changing world, would have been invaluable for enmeshing the study in a broader framework and in linking theory to contemporary real case scenarios. This would have made it easier to determine what the study of realignment tells one about foreign policy in general but specifically in a world of globalization, terrorism, forced displacement, migration, and climate change, just to mention the most prominent characterizing key words.

\subsection{Subsequent Development: The Contribution of Hermann and Rosati}

Over the years, few scholars further developed the concept of FPR. Charles F. Hermann was a key one of those. His studies were presented in the article titled "Changing Course: When Government Choose to Redirect Foreign Policy" (Hermann, 1990). According to Hermann, foreign policy change remains imperative, and it has always been occurring. Hermann argued that attempts at fundamental foreign policy change are of special interest, both because of their domestic and their external consequences: 'Wars may begin or end. Economic well-being may significantly improve or decline. Alliances may be reconfigured. Sometimes the entire international system is affected'. He emphasized "changes that mark a reversal, or at least, a profound redirection of a country's foreign policy are of special interest because of the demands their adoption pose on the initiating government and its domestic constituents and because of their potentially powerful consequences for other countries." Hermann tried to unravel the subsequent questions, "Under what circumstances do these kinds of changes occur in which an existing government recognizes that its current course is seriously inadequate, mistaken, or no longer applicable? What are the conditions under which self-correcting change may arise?" (Hermann, 1990).

Hermann paid attention to the basic FPR of national foreign policy and made a distinction between adjustment changes and major foreign policy redirection. Adjustment and program changes entail tactical movements in the realization stage of a policy or in the methods and means used to meet a foreign policy objective. In both cases, what is done and how it is done changes, but not the policy essence or the policy objectives. Problem/goal and international orientation changes refer to more strategic and fundamental changes in the conceptualization of a foreign policy problem/goal or the redirection of a country's approach to world affairs and position in the international system. Such changes entail the replacement or abandonment of the initial problem/goal and the deriving foreign policy objectives, which may ultimately take the form of an overall international re-orientation of the state and the simultaneous alteration of many of its policies and objectives (Hermann, 1990).

Rosati (1994) offered a unique contribution; a clear account of the application of punctuated equilibrium within the discipline of foreign policy (da Vinha, 2017). Rosati (1994) argued that foreign policy is subject to cyclical dynamics where "the interaction of the state, the society, and the global environment produces a dialectical process where governmental foreign policy evolves through different cycles of phases over time: from a period of stability (or equilibrium) in which continuity in policy tends to prevail to a period of transition (or disequilibrium) in which change in policy is most likely. Governmental foreign policy tends to resist change but is interrupted occasionally by political crises which stimulate change. Should change in foreign policy occur, a new pattern of foreign policy eventually will become established and entrenched in the government, bringing a new period of stability (and equilibrium) in which continuity in policy again prevails. Therefore, an ongoing cyclical process tends to occur where continuity in governmental foreign policy is periodically interrupted by change."

\section{FPR Literature in the Arab World}

\subsection{Beyond Holsti: The Key Contribution in the Arab World}

In their book 'The Foreign Policies of Arab States: The Challenge of Globalization', both Bahgat Korany and Ali E. Hillal Dessouki were notably the only two who managed to tackle FPR in the Arab World yet even there, their contribution fell short by few years as it missed a bigger big bang compared to the two big bangs they have referred to in their book. In their book, both scholars noted the effect of two big bangs on foreign policy change, at the global level, but with a primary focus on the Arab World (Korany \& Dessouki, 2008). According to the authors, those were namely the collapse of the Soviet Union, what the prominent Egyptian writer Muhammad Hasanayn Haykal called the "Soviet earthquake," and the 9 September 2011 attacks against the United States (Korany \& Dessouki, 2008). They started by highlighting the fact that relatively little work has been done to analyze Arab states' foreign policies, and how those countries view the world and their role in it (Korany \& 
Dessouki, 2008). Both argue that most of the literature on the subject matter has been largely of a descriptive or prescriptive genre, devoid of rigorous conceptualization (Korany \& Dessouki, 2008).

The authors' contribution was key to bridge the dysfunctional studies-social sciences polarization and enhance the understanding of Arab foreign policies based on systematic fieldwork and theoretical literature on foreign policy, emphasizing interdependence among the different components, and eventually perceiving foreign policy in the context of its domestic, regional and global surrounding (Korany \& Dessouki, 2008). They, in addition to other authors, then applied the proposed framework chapter by chapter to a number of countries, namely Egypt, Iraq, Jordan, Lebanon, Morocco, Kingdom of Saudi Arabia, Sudan, Syria, and the United Arab Emirates.

The authors further evaluated two major influential approaches in the analysis of foreign policy, namely the traditional realist power school and the (behavioralist/scientific) psychological-idiosyncratic school (Korany \& Dessouki, 2008). They have also noted that debates in the field of international relations have been fueled by the aforementioned big bangs, underlining the fact that war was no longer the sole factor in transforming the global system, aside the rising role of terrorist no-state actors, and the inevitable bringing of religion into the equation (Korany \& Dessouki, 2008). After stressing the key elements of each school and its drawbacks, the authors offered their own analysis of foreign policy output and inputs/determinants, privileging a holistic approach in the definition of foreign policy output/outcome, and conceptualizing foreign policy output as the product of a two-dimensional role of the world stage (Korany \& Dessouki, 2008). Dessouki went one extra mile by offering concrete examples of FPR in Egypt.

Over the last fifty years (noting that the latest edition of the book was published in 2008), Egypt has undergone two FPR processes under presidents Gamal Abd al-Nasser (1955-1970) and Anwar Al Sadat (1970-1981) (Dessouki, 2008). The first one took place during the 50s within the context of liberation from colonialism in the global south. When President Nasser was confronted with a situation whereby the Western powers refused to provide arms to Egypt or to fund the building of the High Dam, he had to change his axis to the East, the Soviet Union, to seek the necessary economic and military aid, entailing a fundamental shift in Egyptian foreign policy (Dessouki, 2008).

During the 70s, Egyptian foreign policy undergone a second FPR under the reign of President Sadat "reflecting a trade-off between economic and political objectives as perceived" by him and entailing distancing himself from the policies of Nasser while adopting a pro-Western posture (Dessouki, 2008). At the domestic level, Sadat changed the name of Egypt, the national flag, as well as the national anthem. Economically, he moved from socialism to economic liberalization. He also gradually replaced the one party system with controlled political pluralism. Regionally, he changed alliances and established stronger relations with pro-Western oil-producing states. He later initiated a peace process with Israel that witnessed his visit to Jerusalem before eventually concluding the Camp David Accords in 1978 and the peace treaty in 1979. At the global level, Egypt shifted from the Soviet camp to the United States camp (Dessouki, 2008). In short, Sadat's policies marked "a radical shift in the underlying elements of Egypt's internal and external policies" (Wesselman, 1995).

\section{Analysis}

While FPR owed credit to Holsti's pioneer work, the minimal subsequent utilization of the term in linkage to the scholar, as demonstrated by the above analysis of referencing in major foreign policy and international relations journals, articles and theses, hence paving the role for succeeding scholars who aimed at advancing the analysis of the term, including Hermann and Rosati, but most importantly applied the FPR theoretical framework to critical regions including the Arab World, for instance the work of Korany \& Dessouki, but one which fell few years short.

But again, why is the interest in the Arab World in the first place? The strategic location of the region, its control of vital waterways, the crucial role played in Islamic, African and Mediterranean fora, and, last but not least, the oil and natural gas wealth, stand out as key factors (Korany \& Dessouki, 2008). Those have added to the centrality of the Middle East with the rising use of 'war on terror,' Islamophobia, invasion of Iraq (Korany \& Dessouki, 2008), not to the mention the post-book mega event of the 'Arab Spring', and its aftermath which was briefly reflected in the article's introduction.

Next, why has the Arab World been plagued by an almost non-existent literature on FPR particularly during the current state of affairs where it is confronting a fluid context that changes almost by the day? According to Korany \& Dessouki, this neglect can be attributed to at least four factors. First, the underdevelopment state of the sub-discipline of foreign analysis with reference to the global south. Indeed, it has been the case that the dynamics of foreign policy have been largely attributed to the personalities and whims of the leaders rather than to rational and calculated policies that emanate from institutional processing in accordance with set strategic 
approaches and guiding policies. Taking the example of Sadat as an example, "most of the writings on Egyptian foreign policy under Sadat attempted to account for the shift in Egyptian foreign policy in his years through examining his personal belief system, which they also held responsible for the simultaneous liberalization of the Egyptian economy (Mahmoud, 2009)."

Second, the limited availability of data coupled with the simultaneous coining of the conduct of foreign policy under labels of, inter alia, 'secrecy', 'national security', and 'black box'. This is directly linked to the first factor. The scarcity of data is associated with the degree of lack of transparency and absence of checks and balances mechanisms in place, as well as accountable institutional actions that could be clearly and indisputably identified, monitored and eventually analyzed and evaluated. Since in many cases only the outcome is what is seen without being privy to how or why the decisions were made in the first place, the associated ambiguity is translated into equally vague terms like the ones mentioned above.

Third, the unbalanced focus on regional political dynamics at the expense of the analysis of single-actor behavior. Usually the obsession is with the changing aspects of the alliances rather than with the motivation of a player. So for instance the temptation would be to focus on who is joining Qatar against Saudi, UAE, Bahrain and Egypt's alliance, who is siding by Iran against the Saudi led coalition in the case of Yemen, who is aligning with the Kurds against Turkey in the case of Syria, who is on the side of Egypt against the Mother Brotherhood and the list goes on and on without particularly shifting the interest to the analysis of why such swings are taking place and how FPR could account, or not, for such ones.

The Last factor according to Korany \& Dessouki is the methodological weakness combined with the lack of analytical thoroughness and precision of the literature on the Arab countries with an overemphasis on historicism and the uniqueness of the Arab-Islamic situation verging on 'Arab exceptionalism' (Korany \& Dessouki, 2008). The tendency remains tilted towards labeling the Arab World as an exception even in the face of well-known and recognized theories of international relations, either because of historic reasons, exclusive context, conspiracy theory, ... etc., and that perceived uniqueness eventually boils down into stereotyping or oversimplifying situations into black and white hence diluting any added value in direct effort to try to uncover what is beyond the seemingly obvious.

\section{Conclusion and Way Forward}

The study of foreign policy formulation is inherently a challenging task, not to mention trying to analyze its restructuring, as it implicates quite a complex mix of factors including, inter alia global ones at the mega level (Snyder et al., 1962; Rosenau, 1972) down to ones at the individual micro level and the associated perceptions and beliefs (de Rivera, 1968; Morgan, 1991). Back in the 1950s, Bernard Cohen stated that "while there may be widespread recognition of the desirability of knowing more about how foreign policy is made, it is far from simple task actually to build up a useful body of relevant knowledge" (Cohen, 1957). As far as FPR is concerned, Holsti took the most important step by coining the concept and designing its skeleton but, like the case with many other notions in various disciplines, that step was only the first and never enough. Continuous efforts are needed and the burden falls on the subsequent scholars to challenge the past and attempt to cater for new developments that require taking fresh perspectives and tackling issues from distinctive angles.

Indeed the study by both Korany \& Dessouki has been particularly important in the field of international relations, and particularly as far as FPR is concerned, for a number of salient reasons, aside filling an obvious gap in the literature dealing with foreign policy change in the Arab World. First, it tackled various levels in foreign policy change, including FPR, within a highly fluid and turbulent region that has continued to be the center of the global foreign policy theatre for various inherent historic, geopolitical and socio-economic factors, in addition to the aforementioned big bangs.

Second, the study did not suggest the holistic framework in vacuum but provided a number of objectively solid case studies that offered both historic and contemporary accounts. The case studies are of prime relevance in analyzing and comprehending, not only the diverse modes of foreign policy change, but, most importantly, the motives behind foreign policy designing and decision-making, with the aim of achieving complex domestic, regional, and international agendas.

Third, the study advocated for an inclusive approach for understanding foreign policy change, which neither reduced foreign policy conduct to affairs solely among state actors reliant on realist concepts nor on the personal traits of the leader in isolation. The suggested approach looked at foreign policy eclectically as a manifestation of both external and domestic policies and as a complex product of diverse collection of dynamic intertwined determinants. Additionally, the work was also valuable in highlighting the fact that while many of the dramatic changes in course occur when new governments with different perceptions and new agendas come to power, a 
number of cases reveal situations in which the same government that initiated a course in foreign policy was the same one that recognized that significant changes must be undertaken.

That being said, and considering the tremendous changes that took place since the 2008 edition and that are currently still taking place in that region, much more sustainable, consistent, impartial, accurate and evidence-based scholastic work is mostly needed to analyze FPR in the Arab World while taking note and cognizance of the aforementioned potential shortcomings. Looking at the two FPR examples that Dessouki (2008) referred to, and notwithstanding the fact that they are almost antiquated with the current pace of contemporary change, the added value was invaluable in merging theory and practice, offering an analytical account, and opening a window for possible understanding of why states act the way they do. Switching to the present, and with the ongoing turbulent and protracted situations in the Arab World, including in Syria, Yemen and Libya, catering for scores of casualties, more than $35 \%$ of the world's refugees and $30 \%$ of the world's internally displaced population as per UNHCR's Global Trends Report (2016) (excluding more than 5.3 million Palestinian refugees registered under UNRWA), and economic losses amounting to hundreds of billions of dollars, the question of why the Arab World remains a heated arena for bloody conflicts remains crucial, heightening the parallel vital need to continuously attempt to understand the behavior of states within the Arab World and the motives and factors behind FPR in this crucial part of the world, a comprehension that may, or may, not exacerbate the current state of turmoil in the Arab World but will at least provide a critical and mostly needed insight.

\section{References}

Cohen, B. (1957). The political process and foreign policy. Princeton: Princeton University Press. https://doi.org/10.1515/9781400878536

da Vinha, Luis (2017). Geographic mental maps and foreign policy change: Re-mapping the Carter Doctrine. Berlin: De Gruyter Oldenbourg, 35. https://doi.org/10.1515/9783110524475

de Rivera, Joseph H. (1968). The psychological dimension of foreign policy. Columbus, Ohio: Charles E. Merrill.

Dessouki, A. E. H. (2008). Regional leadership: Balancing off costs and dividends in the foreign policy of Egypt. In B. Korany, \& Ali. E. H. Dessouki (Eds.), The foreign policies of Arab states: The challenge of globalization (p. 167). Cairo: The American University in Cairo.

Fukuyama, F. (1989). The end of history? National Interest, (Summer), 3-18.

Gilpin, R. (1981). War and change in international politics (p. 406). Cambridge: Cambridge University Press. https://doi.org/10.1017/CBO9780511664267

Goldgeier, J., \& McFaul, M. (1992). A tale of two worlds: Core and periphery in the postcold war era. International Organization, 46(1), 467-492.

Gustavsson, J. (1998). The politics of foreign policy change: Explaining the Swedish reorientation on EC membership. Lund University Press. Retrieved from http://www2.srv.svet.lu.se/Fulltext/Jakob_G.pdf

Hermann, C. (1978). Foreign policy behavior: That which is to be explained. In M. A. East et al. (Eds.), Why nations act. Beverly Hills: Sage Publications.

Hermann, C. (1990). Changing courses: When governments choose to redirect foreign policy. International Studies Quarterly, 34, 3-21. https://doi.org/10.2307/2600403

Hill, C. (2003). What is to be done? Foreign policy as a site for political action. Paper presented at the London School of Economics and Political Science, London. Retrieved from https://www.lse.ac.uk/internationalRelations/pdf/CJHwhatistobedone.pdf

Hoffman, S. (1989). What should we do in the world? Atlantic Monthly, 264(4), 84-96. Retrieved from https://www.theatlantic.com/past/docs/politics/foreign/hoffman.htm

Holsti, K. (1982). Why nations realign: Foreign policy restructuring in the postwar world. London: Allen \& Unwin.

Holsti, K. (1998). The problem of change in international relations theory. Working Paper No. 26. At the University of British Columbia. Retrieved from https://www.files.ethz.ch/isn/46511/WP26.pdf

Huntington, S. (1993). The coming clash of civilizations? Foreign Affairs, 72, 22-49.

Kamo, T. (1994). The internationalization of the state: The case of Japan. In Y. Sakamoto (Ed.), Global Transformation: Challenges to the State System (p. 108). Tokyo: United Nations University. 
Kaplan, R. D. (1994). The coming anarchy. The Atlantic Monthly, February, 44-76. Retrieved from https://www.theatlantic.com/past/docs/politics/foreign/hoffman.htm

Karawan, I. (2006). Foreign policy restructuring: Egypt's disengagement from the Arab-Israeli conflict revisited. Cambridge Review of International Affairs, 18, 325-338. https://doi/abs/10.1080/09557570500237821

Korany, B., \& Dessouki, A. E. H. (2008). Foreign policy analysis in the global era and the world of the Arabs. In B. Korany, \& A. E. H. Dessouki, (eds.) The foreign policies of Arab states: The challenge of globalization (p. 22). Cairo: The American University in Cairo.

Korany, B., \& Dessouki, A. E. H. (2008). Foreign policy approaches and Arab countries: A critical evaluation and an alternative framework. In B. Korany, \& A. E. H. Dessouki, (eds.) The foreign policies of Arab states: The challenge of globalization (p. 22). Cairo: The American University in Cairo.

Korany, B., \& Dessouki, A. E. H. (Eds.) (2008). The foreign policies of Arab states: The challenge of globalization. Cairo: The American University in Cairo Press.

Koslowski, R., \& Kratochwil, F. (1994). Understanding change in international politics: The Soviet empire's demise and the international system. International Organization, 48(2), 215-248. Retrieved from http://www3.nccu.edu.tw/ lorenzo/Koslowski\%20Soviet\%20Demise.pdf

Mahmoud, Y. M. E. M. (2009). A political economy of Egyptian foreign policy: State, ideology, and modernization since 1970 (Doctoral dissertation). Retrieved from http://etheses.lse.ac.uk/2753/1/U615702.pdf

Morgan, P. (1991). Psychological aspects of foreign policy. Issues in World Politics Series, Lexington Books.

Mueller, J. (1989). Retreat from doomsday: The obsolescence of major war. New York, NY: Basic Books.

Rosati, J. A. (1994). A cognitive approach to the study of foreign policy. In J. A. Rosati, J. D. Hagan, \& M. W. Sampson III (Eds.), Foreign policy restructuring: How governments respond to global change (p. 52). Columbia: University of South Carolina Press.

Rosati, J. A., Hagan, J. D., \& Sampson III, M. W. (1994). Foreign policy restructuring: How governments respond to global change. Columbia: University of South Carolina Press.

Rosenau, J. N. (1972). The external environment as a variable in foreign policy analysis. In J. Rosenau, V. Davis, \& M. East (Eds.), The analysis of international politics (pp. 145-165). New York: The Free Press.

Rosenau, J. N. (1990). Turbulence in world politics: A theory of change and continuity. Princeton: Princeton University Press.

Rosenau, J. N. (1997). Along the domestic-foreign frontier: exploring governance in a turbulent world (p. 7) Cambridge: Cambridge University Press. https://doi.org/10.1017/CBO9780511549472

Sakamoto, Y. (1994). Global transformation: Challenges to the state system (pp. 15-16). Tokyo: United Nations University Press.

Singer, M., \& Wildavsky, A. (1993). The real world order: Zones of peace zones of turmoil. Chatham, NJ: Chatham House Publishers.

Snyder, R., Bruck, H.W., \& Spain, B. (1962). Foreign policy decision making. New York: Free Press.

Wallace, R. M. M. (1997). International Law (pp. 1-2). London: Sweet \& Maxwell.

Wesselman, W. D. (1995). U.S. foreign policy decision-making during the 1973 Arab/Israel conflict: Its impact on Soviet-Egyptian foreign policy relations. Alabama: Maxwell Air Force Base. https://doi.org/10.21236/ADA328955

\section{Copyrights}

Copyright for this article is retained by the author(s), with first publication rights granted to the journal.

This is an open-access article distributed under the terms and conditions of the Creative Commons Attribution license (http://creativecommons.org/licenses/by/4.0/). 